\title{
Decompressive Craniectomy for Viral Encephalitis: Two Case Reports
}

\section{Craniectomia descompressiva para encefalite viral: relato de dois casos}

\author{
Ricardo Lourenço Caramanti ${ }^{1}$ Eduardo Cintra Abib ${ }^{1}$ Dionei Freitas de Moraes ${ }^{2}$ \\ Eduardo Carlos da Silva ${ }^{2}$ Carlos Eduardo D’Aglio Rocha ${ }^{2}$ Fabiano Morais Nogueira ${ }^{2}$
}

\footnotetext{
${ }^{1}$ Neurosurgery Service, Hospital Austa, São José do Rio Preto, SP, Brazil

2 Department of Neurosurgery, Faculdade de Medicina de São José do Rio Preto, São José do Rio Preto, SP, Brazil
}

Address for correspondence Ricardo Lourenço Caramanti, MD, Hospital Austa, Av. Murchid Homsi, 1385 - Parque Residencial Mançor Daud, São José do Rio Preto, SP, Brazil 15070-650

(e-mail: rcaramanti@hotmail.com).

Arq Bras Neurocir 2018;37:231-234

\begin{abstract}
Keywords

- viral encephalitis

- decompressive craniectomy

- intracranial hypertension

A decompressive craniectomy is a therapeutic modality not commonly used in cases of refractory intracranial hypertension due to viral encephalitis. In this article the authors present two cases of patients with viral encephalitis that have undergone decompressive craniectomy to control intracranial pressure. Both evolved with Glasgow outcome score of 4 . The main clinical data for the surgical decision are Glasgow coma scale and the pupils of the patient associated with the imaging tests showing a large necrotic area and perilesional edema. The evolution of the patients undergoing decompression was satisfactory in $92.3 \%$ of cases.

\section{Resumo}

Palavras-Chave

- encefalite viral

- craniectomia descompressiva

- hipertensão intracraniana

A craniectomia descompressiva é uma modalidade terapêutica de rara utilização em casos de hipertensão intracraniana refratária por encefalite viral. No presente artigo os autores descrevem dois casos de pacientes com encefalite viral que foram submetidos a craniectomia descompressiva para controle da pressão intracraniana. Ambos evoluiram com Glasgow outcome score de 4 . Os principais dados clínicos para a decisão cirúrgica são a pontuação segundo a escala de coma de Glasgow e as pupilas do paciente, associados a exames de imagem exibindo grande área necrótica e edema perilesional. A evolução dos pacientes submetidos à descompressão mostrou-se satisfatória em 92,3\% dos casos.
\end{abstract}

\section{Introduction}

Decompressive craniectomy is a therapeutic modality widely recognized in the literature for the control of intracranial hypertension in trauma and cerebral hemorrhages, but its use in cases of viral encephalitis is still controversial.

Intensive care, antiviral drugs, corticosteroids, hyperosmolar therapy and hyperventilation are sufficient for the resolution of edema in most patients, with rare cases in which surgical intervention to reduce the intracranial pressure becomes necessary. ${ }^{1-4}$

To date, the literature shows some reports of isolated cases, with a good evolution of the patients after the decompression procedure.

In the present article, we describe the experience of our service with the report of two cases, in addition to a literature review. received

September 29, 2015

accepted

November 23, 2015

published online

February 16, 2016
DOI https://doi.org/

10.1055/s-0036-1572505. ISSN 0103-5355.
Copyright $\odot 2018$ by Thieme Revinter

Publicações Ltda, Rio de Janeiro, Brazil
License terms

() (1) $\Theta \circledast$ 


\section{Case Reports}

\section{Case 1}

A female patient, 18 years old, presented with somnolence and headache accompanied by fever for a week. At the physical examination, the patient was slow but conscious and oriented, with no focal signs or pupillary alterations. Basic biochemistry exams revealed a discrete leukocytosis.

A magnetic resonance imaging (MRI) exam showed hypersignal in a region of the right temporal lobe suggestive of herpetic encephalitis.

A cerebrospinal Fluid (CSF) scan showed leukocytes $=543$, lymphocytes $=90 \%$, proteins $=79$, and glucose $=52$.

Aciclovir was then started intravenously. However, after 2 days, there was a decrease in the level of consciousness to Glasgow coma scale of 6 , besides a discrete anisocoria on the right side. A computed tomography (CT) showed an area of temporal hypodensity with signs of intracranial hypertension. We chose to perform an emergency decompressive craniectomy on the right side.

The patient evolved with improvement of the clinical picture, and acyclovir was used for 28 days. There was complete improvement as observed in the follow-up CSF scan.

After 2 months of evolution, the patient presented no motor sequelae, with Glasgow outcome score of 4, maintaining a discreet memory deficit. She was submitted to cranioplasty (-Fig. 1).

\section{Case 2}

A male patient, 30 years old, presented with severe headache, vomiting and behavioral changes for 3 days that evolved with a decrease in the level of consciousness to glasgow coma scale of 8 . The physical examination showed anisocoria on the right side.

An MRI scan evidenced a hypersignal region in the right temporal lobe with extension to the parietal region, in addition to stem compression, suggestive of herpetic encephalitis.

The patient underwent a decompressive craniectomy on the right with the use of a frontal intracranial pressure (ICP) monitoring catheter on the same side, and acyclovir was started during the procedure.

The patient evolved with the maintenance of a mean ICP of 7 after the decompression. The catheter was removed after

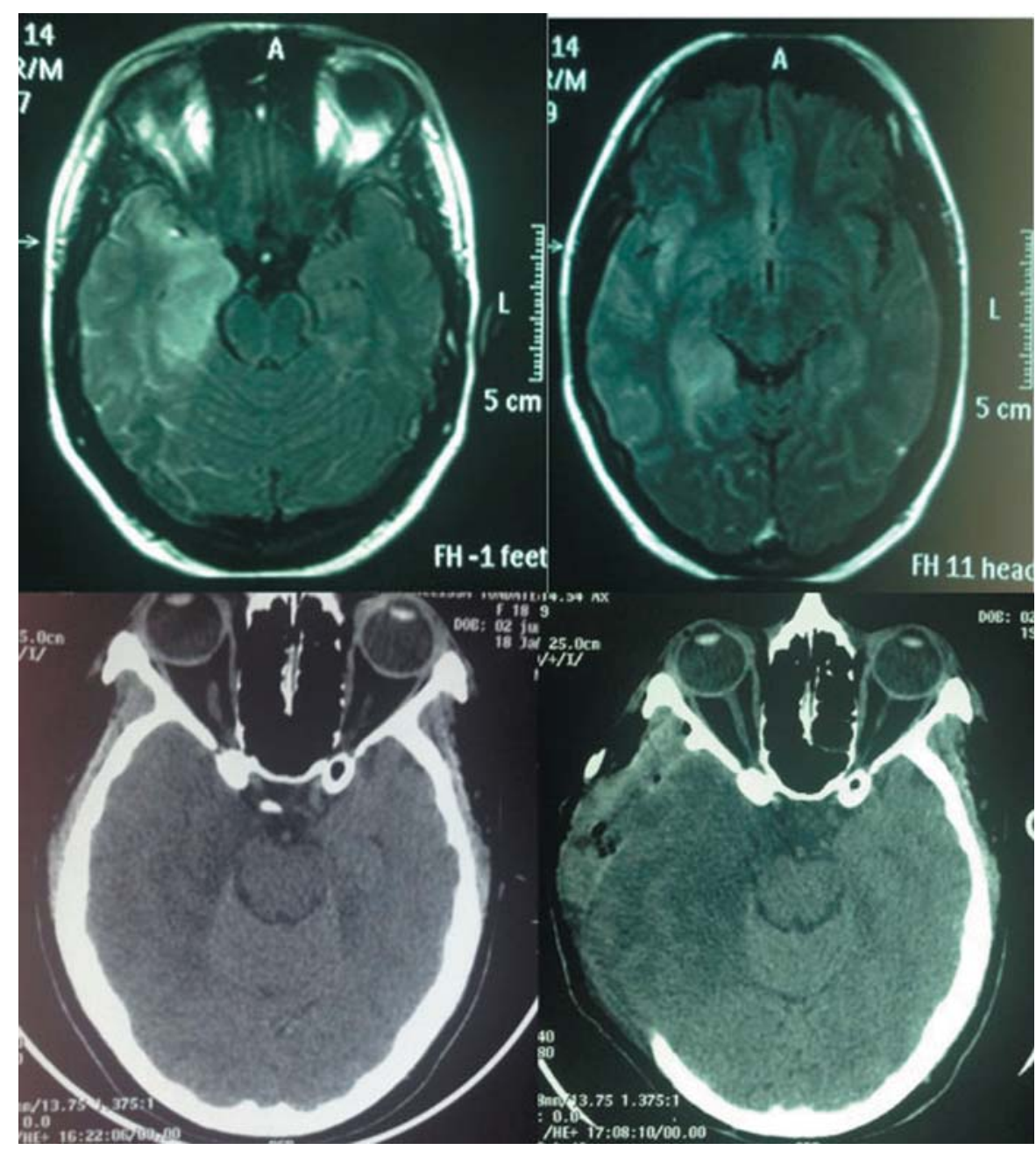

Fig. 1 (A, B) Flair magnetic resonance imaging scan after contrast showing hypersignal in the right temporal region and an edema suggestive of herpetic encephalitis. (C) Computed tomography (CT) scan showing hypodensity with signs of right temporal intracranial hypertension. (D) CT scan showing postoperative status with open base cisterns. 


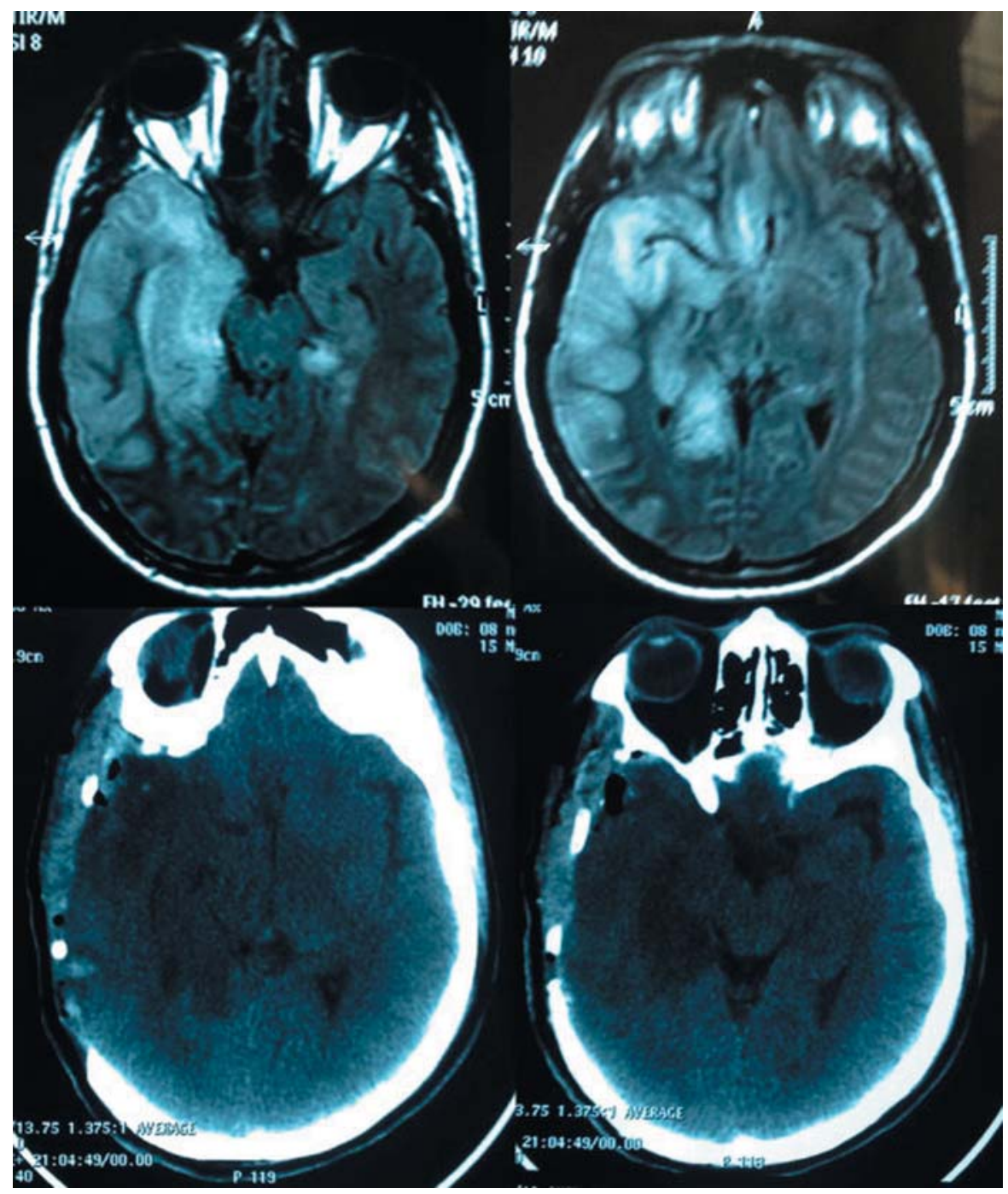

Fig. 2 (A, B) Flair magnetic resonance imaging scan showing hypersignal in the right temporal lobe region with parietal and frontal extension; there are signs of right brain stem compression. $(C, D)$ Postoperative decompressive craniectomy on the right.

3 days, and a control CT was performed on the 4th day (-Fig. 2). There was a progressive clinical improvement, and the patient was discharged from the hospital with a Glasgow outcome score of 4 .

\section{Discussion}

Acute encephalitis is a disease caused by several types of pathogens. Among them, herpes simplex virus type 1 (HSV1 ) is the most common in our country, with an incidence of 7.4 cases per 100,000 inhabitants. If left untreated, its mortality rate becomes high, reaching $70 \%$ of the cases. After the start of the treatment, the mortality rate is $30 \%{ }^{5-8}$

The pathogenesis of herpetic encephalitis remains uncertain, with the most likely hypothesis being the reactivation of the latent HSV-1 virus in the trigeminal ganglion, which then ascends to the central nervous system (CNS), where it causes lesions more commonly in the frontal and temporal lobes. A rarer hypothesis would be a primary infection, in which the HSV-
1 would reach the CNS via the nasal mucosa and the olfactory bulb, staying mainly in the temporal and limbic lobes. ${ }^{9,10}$

The lesions are of a necrotizing nature, with the formation of perilesional edema. This generates an increase in the intracranial pressure and eventually causes a herniation of the uncus with compression of the brainstem, leading to a decrease in the level of consciousness, pupillary asymmetries and motor deficits. However, diffuse cerebral dysfunction, unlike traumatic lesions, seems to occur without alterations in vascular self-regulation. Intracranial hypertension tends to appear slowly, progressing with cerebral inflammation, with its peak occurring from days to weeks after the onset of the symptoms. ${ }^{5,6,11,12}$

Clinically, in addition to the focal signs, the disease is manifested by fever with headache, sometimes associated with changes in the level of consciousness or in the personality, nausea, seizures, nuchal rigidity, photophobia, vomiting, lethargy and myalgia, eventual cutaneous rash, lymphadenopathy, and hepatosplenomegaly. ${ }^{13}$ 
The radiological evaluation should be done preferably by MRI, which shows hypersignal in T2, especially in the temporal and frontobasal regions, and sometimes in the thalamus and in the nuclei of the base. ${ }^{14}$

Whitley et al evidenced that the Glasgow coma scale of patient must be taken into account for the decision of decompressive craniectomy because it is recognized as a prognostic factor. Age did not present itself as a good predictor of evolution. ${ }^{15,16}$

In relation to the management with ICP monitoring, Matthew et al. reported 13 patients, 10 of whom progressed to decompressive craniectomy. ${ }^{17}$

The craniectomy should be adequate for the area of encephalitis edema, and bicoronal hemicraniectomy may be performed for bilateral or even suboccipital frontotemporal involvement when the edema involves the posterior fossa. ${ }^{18-20}$

Pérez-Bovet et $\mathrm{al}^{12}$ showed that patients submitted to decompressive craniectomy had a satisfactory evolution in 92.3\% of the cases, remaining with independent functional status. There was only a $3.8 \%$ mortality rate in their sample, corroborating the evolution of the two cases reported in the present study, which evolved with a Glasgow outcome score of $4.1,12,17$

\section{Conclusion}

Although it is still controversial in the literature, the indication of decompressive craniectomy should be considered for patients with viral encephalitis who have signs of intracranial hypertension associated with worsening of brain edema evidenced by imaging examination. Decompressive craniectomy may provide treatment of intracranial hypertension with good long-term evolution.

\section{References}

1 Safain MG, Roguski M, Kryzanski JT, Weller SJ. A review of the combined medical and surgical management in patients with herpes simplex encephalitis. Clin Neurol Neurosurg 2015;128:10-16

2 Singhi P, Saini AG, Sahu JK, et al. Unusual Clinical Presentation and Role of Decompressive Craniectomy in Herpes Simplex Encephalitis. J Child Neurol 2015;30(09):1204-1207
3 Kannu P, Pinnock R. Uncommon complication of herpes simplex encephalitis. J Paediatr Child Health 2004;40(12):711-713

4 Barnett GH, Ropper AH, Romeo J. Intracranial pressure and outcome in adult encephalitis. J Neurosurg 1988;68(04):585-588

5 Taferner E, Pfausler B, Kofler A, et al. Craniectomy in severe, lifethreatening encephalitis: a report on outcome and long-term prognosis of four cases. Intensive Care Med 2001;27(08):1426-1428

6 Whitley RJ. Herpes simplex encephalitis: adolescents and adults. Antiviral Res 2006;71(2-3):141-148

7 Steiner I, Budka H, Chaudhuri A, et al. Viral encephalitis: a review of diagnostic methods and guidelines for management. Eur J Neurol 2005;12(05):331-343

8 Stula D, Müller HR, Lévy A. [Decompressive craniotomy in herpes simplex encephalitis]. Schweiz Med Wochenschr 1979;109(24): 914-916

9 Silva GMM. Encefalites Virais Agudas. Rev Prática Hosp Infectol 2005;7(40):42-47

10 Kennedy PGE, Chaudhuri A. Herpes simplex encephalitis. J Neurol Neurosurg Psychiatry 2002;73(03):237-238

11 Baringer Jr. Herpes simples virus infections of the nervous system. En: Vinken PJ, Bruyn GW eds. Handbook of Clinical Neurology. Amsterdam: North-Holland Publishing Company; 1978:145-159

12 Pérez-Bovet J, Garcia-Armengol R, Buxó-Pujolràs M, et al. Decompressive craniectomy for encephalitis with brain herniation: case report and review of the literature. Acta Neurochir (Wien) 2012; 154(09):1717-1724

13 Bloch KC, Glaser C. Diagnostic approaches for patients with suspected encephalitis. Curr Infect Dis Rep 2007;9(04):315-322

14 Tunkel AR, Glaser CA, Bloch KC, et al; Infectious Diseases Society of America. The management of encephalitis: clinical practice guidelines by the Infectious Diseases Society of America. Clin Infect Dis 2008;47(03):303-327

15 Whitley RJ, Kimberlin DW. Herpes simplex encephalitis: children and adolescents. Semin Pediatr Infect Dis 2005;16(01):17-23

16 Lahat E, Barr J, Barkai G, Paret G, Brand N, Barzilai A. Long term neurological outcome of herpes encephalitis. Arch Dis Child 1999; 80(01):69-71

17 Adamo MA, Deshaies EM. Emergency decompressive craniectomy for fulminating infectious encephalitis. J Neurosurg 2008;108 (01):174-176

18 Kirkham FJ, Neville BG. Successful management of severe intracranial hypertension by surgical decompression. Dev Med Child Neurol 1986;28(04):506-509

19 Page LK, Tyler HR, Shillito J Jr. Neurosurgical experiences with herpes simplex encephalitis. J Neurosurg 1967;27(04):346-352

20 Perin A, Nascimben E, Longatti P. Decompressive craniectomy in a case of intractable intracranial hypertension due to pneumococcal meningitis. Acta Neurochir (Wien) 2008;150(08):837-842, discussion 842 